\title{
Interpreting change through legal culture: the case of the Irish exclusionary rule
}

\author{
Claire Hamilton ${ }^{\star \dagger}$ (D) \\ Department of Law, Maynooth University, Maynooth, Ireland \\ *Author email: claire.hamilton@mu.ie
}

(Accepted 14 December 2020)

\begin{abstract}
The changes to the Irish exclusionary rule introduced by the judgment in People (DPP) $v$ JC mark an important watershed in the Irish law of evidence and Irish legal culture more generally. The case relaxed the exclusionary rule established in People (DPP) $v$ Kenny, one of the strictest in the common law world, by creating an exception based on 'inadvertence'. This paper examines the decision through the lens of legal culture, drawing in particular on Lawrence Friedman's distinction between 'internal' and 'external' legal culture to help understand the factors contributing to the decision. The paper argues that Friedman's concept and, in particular, the dialectic between internal and external legal culture, holds much utility at a micro as well as macro level, in interrogating the cultural logics at work in judicial decision-making.
\end{abstract}

Keywords: criminal justice; law of evidence; $D P P$ v JC; exclusionary rule; legal culture

\section{Introduction}

'DPP v JC has everything: law, literature, history, polemic and vast learning but also emotion, horror, anger, even shame.'

On 15 April 2015 the Irish Supreme Court delivered what Niall Fennelly, a retired judge of the Supreme Court and former Advocate General of the European Court of Justice, has described as 'the most astounding judgment ever handed down by an Irish court'. ${ }^{2}$ The decision of DPP $v J C^{3}$ made dramatic changes to the Irish law on improperly obtained evidence, revealing deep ideological divisions within the current Supreme Court, and prompting passionate protests from the minority. ${ }^{4}$ By the slimmest of majorities, ${ }^{5}$ the Court overhauled one of the strictest exclusionary rules in the common law world by introducing an exception based on 'inadvertence'. ${ }^{6}$ The consequences are that

\footnotetext{
${ }^{\dagger}$ I am very grateful to Professor David Nelken, Professor Shane Kilcommins and Barry Vaughan for their insightful comments on an earlier draft. I would like to express my thanks also to the journal's anonymous reviewers for their valuable input.

${ }^{1} \mathrm{~N}$ Fennelly 'The judicial legacy of Mr Justice Adrian Hardiman' (2017) 58 The Irish Jurist 81 at 91.

${ }^{2}$ Ibid.

${ }^{3}$ [2015] IESC 31, [2017] 1 IR 417.

${ }^{4}$ See further C Ni Choilean and A Bazarchina 'Admissibility of unconstitutionally obtained evidence after DPP v JC' (2015) 20(4) Bar Review 83.

${ }^{5}$ The Court was divided 4-3 in favour of the reform, Denham CJ, Clarke, O'Donnell and MacMenamin JJ in the majority; Hardiman, Murray and McKechnie JJ dissenting. The then Chief Justice, Ms Justice Denham, did not deliver a judgment.

${ }^{6} \mathrm{Y}$ Daly 'Police and judicial functions: recent developments in criminal procedure' (2011) 1 Criminal Law and Procedure Review 22 at 43.

(c) The Author(s), 2021. Published by Cambridge University Press. This is an Open Access article, distributed under the terms of the Creative Commons Attribution licence (http://creativecommons.org/licenses/by/4.0/), which permits unrestricted re-use, distribution, and reproduction in any medium, provided the original work is properly cited.
} 
evidence obtained unconstitutionally can now be admitted where officers of the State claim to have no knowledge of the breach (the so-called 'green garda'/'good faith' exception). ${ }^{7}$

The aim of this paper is to examine the decision not so much in terms of its legal effects, important though they may be, but rather, as a watershed moment in the Irish criminal justice system, and indeed in Irish legal culture more generally. ${ }^{8}$ In seeking to interpret such change the paper draws on Lawrence Friedman's concept of legal culture, first introduced as a 'term of art' in 1975, ${ }^{9}$ and subsequently generating an impressive body of literature. ${ }^{10}$ This paper argues for the utility of the concept, particularly the division between internal and external legal culture, in understanding the 'permeability of law to social demands' at the micro level of judicial decision-making as well as the macro level envisaged by Friedman. ${ }^{11}$ Using the debate over the recent reforms to the Irish exclusionary rule as a case study, it asks what factors contributed to the demise of a 'due process' oriented legal culture in Ireland in recent decades, embodied, perhaps symbolically, in the watershed JC decision. In responding to this question, the paper extols, following Friedman, the virtues of 'start[ing] from the outside rather than the inside,, ${ }^{12}$ but with a careful eye also to the mediating effects of a (contested) internal legal culture that is far from the dope of structural forces. It proceeds as follows. Following some discussion outlining the meaning of the term 'legal culture' for present purposes, it moves to examine the due process oriented legal culture that I contend existed in Ireland since the 1960s and the import of $J C$ for this culture. Friedman's concepts of internal and external legal culture are then deployed to examine the backdrop to the JC decision, including criticism levelled at the exclusionary rule both within and outside of legal doctrine. The paper concludes by linking this interplay to broader cultural shifts towards a more expressive and populist justice system.

\section{The meaning of legal culture}

Given the long debate over the meaning and usefulness of the legal culture concept, matters of definition and approach assume a particular importance. Friedman was interested in the pressures that social and technological developments build up in bringing about legal change, and, to this end, famously posited a distinction between 'internal' and 'external' legal culture. 'Internal legal culture' refers to the ideas and behaviour of those within the law such as lawyers or judges. 'External legal culture', on the other hand, points to the pressures brought to bear on law from wider society and includes ordinary people's attitudes towards the law and whether or not they trust legal institutions. Despite its persistence in the literature and in common usage, the concept of legal culture has been heavily critiqued. ${ }^{13}$ It has been said that the concept is vague, prone to tautology and has been used inconsistently over the years. ${ }^{14}$ It has also been argued that analyses basing themselves on legal culture presume a relatively homogenous and static concept of culture that has been found to be problematic in

\footnotetext{
${ }^{7} \mathrm{C}$ Hamilton 'Green guards, good faith and the exclusionary rule' (2015) Aug/Sep Gazette of the Incorporated Law Society of Ireland 20.

${ }^{8} \mathrm{Admittedly,} \mathrm{this} \mathrm{is} \mathrm{to} \mathrm{take} \mathrm{the} \mathrm{position} \mathrm{that} \mathrm{JC} \mathrm{marks} \mathrm{an} \mathrm{important} \mathrm{'revolution} \mathrm{in} \mathrm{principle',} \mathrm{to} \mathrm{again} \mathrm{borrow} \mathrm{the} \mathrm{words} \mathrm{of}$ Hardiman $\mathrm{J}$ in $J C$, whereas others have sought to downplay the effects of the decision (see, in particular, C Leon and T Ward 'The Irish exclusionary rule after DPP v JC' (2015) 35(4) Legal Studies 590, who argue that it is actually quite a limited retreat from previous jurisprudence). The preponderance of the literature, however, acknowledges that this is a significant decision in Irish evidential law, albeit one whose impact has yet to be fully revealed at an appellate level. See, for example, Y Daly "'A revolution in principle"? The impact of the new exclusionary rule' (2018) 2 Criminal Law and Practice Review 1.

${ }^{9}$ L Friedman The Legal System: A Social Science Perspective (Russell Sage Foundation, 1975).

${ }^{10}$ Merry describes it as 'enormously productive'. See S Merry 'What is legal culture? An anthropological perspective' (2010) 5 Journal of Comparative Law 40 at 40.

${ }^{11} \mathrm{D}$ Nelken 'Defining and using the concept of legal culture' in E Örücü, and D Nelken (eds) Comparative Law: A Handbook (Oxford: Hart Publishing, 2007) p 109 at p 116.

${ }^{12}$ L Friedman 'The concept of legal culture: a reply' in D Nelken (ed) Comparing Legal Cultures (London: Routledge, 1997) p 33.

${ }^{13}$ For an overview see R Michaels 'Legal culture' in J Basedow et al (eds) Max Planck Encyclopedia of European Private Law (2012).

${ }^{14}$ See in particular R Cotterrell 'The concept of legal culture' in Nelken, above n 12.
} 
other disciplines such as anthropology and sociology. ${ }^{15}$ On this view, the trope of legal culture denotes something that is particular and permanent, within clearly defined borders. ${ }^{16}$ Finally, critics take issue with the presumption that culture exerts influence on law, without sufficient appreciation of the influence that law exerts over culture. ${ }^{17}$ While there is merit in such criticisms, as will be discussed below, many of these problems can be avoided through careful attention to questions such as the type of facts that are being examined in any given case study. It is also important to recognise that Friedman's concept of legal culture is itself flexible and dynamic, and indeed one which was developed originally to investigate the impact on modernity on law, as we move to a global legal culture based around the ideas of individualism, equality and rights. His is therefore a view of legal culture that 'is dynamic and responsive, not genetic'. ${ }^{18}$

Nelken ${ }^{19}$ offers a way through the mire of confusion and ambiguity surrounding the concept by encouraging authors to make explicit three matters that are often assumed in studies of legal culture: (i) the kind of facts that are thought to make up legal culture; (ii) the chosen approach within which the concept is deployed; and (iii) the normative aspects of the enquiry. In relation to the first issue, following Friedman, I have adopted a definition of legal culture as 'values, opinions, attitudes and beliefs about law. ${ }^{20}$ While the unit of analysis here is the criminal justice culture of the Irish state since it achieved its independence in 1921, it is important to stress that there is neither an assumption of permanence, nor one of coherence. In line with Friedman's original approach the emphasis is on change, prompted on this occasion not as a result of new inventions (such as birth control pills) or situations (such as war), but putatively as the emergence of a more populist and victim-oriented justice system. ${ }^{21}$ Further, as the deeply divided court in the JC decision attests, legal opinion on the appropriateness of change in this area remains a matter of keen debate, with much uncertainty as to the manner in which it is being implemented. As to the second issue of the approach within which the concept is deployed, legal culture is here being invoked less as a causal explanation (explanans) and more as something that itself needs to be explained (explanandum). As will be elaborated in the next section, Ireland's exclusionary rule prior to the JC decision was one of the strictest in the common law world, with some arguing that even post- $J C$ it remains 'unusually rigid'. ${ }^{22}$ Viewed against a strong 'rule of law' framework, and tendency towards 'liberal legalism', ${ }^{23}$ the query is first, what factors helped to forge this distinctive legal culture in post-independence Ireland and secondly, what factors have contributed to its demise in recent decades, embodied, perhaps symbolically, in the watershed JC decision. In terms of the normative orientation of the enquiry, as Nelken observes, the term is sometimes

\footnotetext{
${ }^{15}$ See Merry, above n 10, at 41-42 for a discussion on the anthropological literature. On sociology see, for example, C Rojek and B Turner 'Decorative sociology: towards a critique of the cultural turn' (2000) 48(4) The Sociological Review 629.

${ }^{16}$ See Merry, above $\mathrm{n} 10$, for a review of this line of criticism.

${ }^{17}$ S Silbey 'After legal consciousness' (2005) 1 Annual Review of Law and Social Science 323. See also S Silbey 'Legal culture and legal consciousness' (2001) International Encyclopedia of the Social \& Behavioral Sciences 8623 at 8628 , where she argues that in constitutive studies of legal culture/consciousness, 'law is understood to be part of a complex totality in which it constitutes as well is constituted, shapes as well as is shaped'.

${ }^{18} \mathrm{~T}$ Ginsburg 'Lawrence M Friedman's comparative law, with notes on Japan' (2010) 5 Journal of Comparative Law 92 at 99.

${ }^{19} \mathrm{D}$ Nelken 'Comparative legal research and legal culture: facts, approaches, and values' (2016) 12 Annual Review of Law and Social Science 45.

${ }^{20} \mathrm{~L}$ Friedman 'Some thoughts on the rule of law, legal culture and modernity in comparative perspective' in Institute of Comparative Law in Japan (ed) Toward Comparative Law in the 21st Century (1998) p 1075. Given suggestions below that due process values extend beyond the judiciary, the paper will focus on broader legal culture rather than simply judicial culture.

${ }^{21}$ See in this regard D Garland Culture of Control (Oxford: Oxford University Press, 2001).

${ }^{22}$ Leon and Ward, above n 8, at 593.

${ }^{23}$ S Kilcommins 'Crime control, the security state and constitutional justice in Ireland: discounting liberal legalism and deontological principles' (2016) 20(4) The International Journal of Evidence \& Proof 326. See also B Vaughan and S Kilcommins Terrorism, Rights and the Rule of Law: Negotiating Justice in Ireland (Cullompton: Willan, 2008) (Chapters 1 and 5) and C Hamilton Reconceptualising Penality: A Comparative Perspective on Punitiveness in Ireland, Scotland and New Zealand (London: Routledge, 2014) (ch 6).
} 
used in the more normative and evaluative sense of a 'culture of legality' rather than as a descriptive or explanatory term. In this regard, it is important to reiterate that the aim of the exercise is not to invoke the term as a call for more legality, as it is used on the ground in other jurisdictions, but rather to examine the $J C$ decision through the lens of legal culture. ${ }^{24}$ To this end, the paper will engage in a close analysis of the background to and judgments in the JC decision and related case law, including review of the relevant legal and criminological literature, policy documents and reports. It is therefore primarily concerned with legal and policy discourses, complemented where possible with empirical evidence relating to legal practices in this area. In this regard the analysis is somewhat hamstrung by a dearth of appellate decisions on the exclusionary rule post- $J C,{ }^{25}$ although some insight into the impact of the decision on practice is provided by a recent report published by the Irish Council for Civil Liberties (ICCL). ${ }^{26}$

\section{Legal culture in Ireland}

As in many other areas of Irish constitutional law, the origins of a distinctively Irish approach to criminal justice can be traced, not to the letter of the 1937 Irish Constitution itself, but to an outburst of judicial activity in the 1960s. This decade marked an important shift in judicial thinking on defendants' rights, such that:

within a period of just a few years, the [Supreme] court was to overhaul a largely informal system in which illegally obtained evidence was regularly used to convict people, suspects were detained 'for questioning' for a number of days by the gardaí (Irish police) and bail was practically unavailable for serious crimes. ${ }^{27}$

The vehicle for the construction of such a 'meta-Constitution'28 on the rights of the accused was active judicial review in the American tradition, and its architects a new generation of liberal-minded Supreme Court judges such as Cearbhall Ó'Dálaigh, TC Kingsmill Moore and Brian Walsh. ${ }^{29}$ As to the genesis of this shift, JM Kelly, one of the leading commentators on Irish constitutional law, may well have been correct that such worldviews were only natural among a group of legal scholars who had gone through university from the mid-1930s, and for whom state excesses at home and abroad (fascism, McCarthyism, Orangeism) were far from academic. ${ }^{30}$ In addition to this, however, there was also a strong nationalistic impulse to forge a body of jurisprudence distinct from that of Britain, a project not confined to criminal law and procedure. Thus, Brian Walsh, one of the driving forces behind this 'legal revolution', ${ }^{31}$ wrote in the foreword to a torts law book published in 1981 'that it had not been recognised hitherto in Irish legal practice that the man on the Crumlin omnibus was

\footnotetext{
${ }^{24}$ As a former criminal defence barrister and author of a book on the erosion of the presumption of innocence in Ireland, however, I cannot claim to be writing from an entirely neutral or value free perspective. See C Hamilton The Presumption of Innocence in Irish Criminal Law: Whittling the Golden Thread (Dublin: Irish Academic Press, 2007).

${ }^{25}$ For a review of the limited jurisprudence to date, see Daly, above $\mathrm{n} 8$. As she writes, 'no great sense of clarity has yet come through the case law'.

${ }^{26} \mathrm{C}$ Hamilton (with S Gough) A Revolution in Principle: Assessing the Impact of the New Evidentiary Exclusionary Rule (Dublin: ICCL, 2020), available at https://www.iccl.ie/wp-content/uploads/2020/10/A-Revolution-in-Principle.pdf (last accessed 25 February 2021).

${ }^{27} \mathrm{R}$ Mac Cormaic The Supreme Court (London: Penguin, 2016) p 96.

${ }^{28}$ See further P O’Mahony ‘The constitution and criminal justice' in P O’Mahony (ed) Criminal Justice in Ireland (Dublin: Institute of Public Administration, 2002) p 183 at p 187.

${ }^{29}$ The primary authors of this period of constitutional expansionism were viewed as Brian Walsh and Cearbhall O'Dalaigh. Colm Toibin, in his article 'Inside the Supreme Court' in Magill (February 1985) writes that 'while O'Dalaigh may have been firing the bullets, Walsh was loading the pistol'. Cited in Mac Cormaic, above n 27, p 106.

${ }^{30} \mathrm{JM}$ Kelly The Irish Constitution (Dublin: Jurist Publishing Company, $1^{\text {st }}$ edn, 1980) pp xxx-xxxi. He also points, more prosaically, to the fact that most of the judges were schooled in constitutional law by a UCD Professor, Patrick McGilligan, with strong beliefs in vigorous judicial review.

${ }^{31} \mathrm{Mac}$ Cormaic, above n 27, Chapter 5 and passim.
} 
not same as the man on the Clapham omnibus' ${ }^{32}$ To further emphasise the break with British law, the Supreme Court signalled a significantly increased receptiveness to American law and practices and Walsh himself systematically monitored US Supreme Court jurisprudence during the 'golden era' of judicial enumeration of constitutional rights. Indeed, Walsh was in personal contact with one of its leading lights, Mr Justice William Brennan, and the two exchanged letters and judgments on matters of mutual interest. Walsh's remark, in the course of one of these exchanges that 'perhaps not surprisingly, our views do not find full favour with the police authorities or indeed with the Department of Justice, ${ }^{33}$ reveals a vision for an indigenous criminal justice system unshaken by the disapproval, even anger, of Justice officials.

These tensions inevitably played out on the stage of the long line of litigation on unconstitutionally obtained evidence. One of the landmark decisions of the 1960s was People (AG) v O'Brien, ${ }^{34}$ which altered the law so that evidence obtained in breach of a constitutional right should normally be excluded. In O'Brien, the probative evidence was found in a search by An Garda Síochána of a home at 118 Captain's Road. However, due to an administrative error, the warrant that the search was predicated upon was issued with the wrong address: 118 Cashel Road. Despite the accused's argument that the evidence should be excluded because it had been obtained in breach of his constitutional right to inviolability of the home, ${ }^{35}$ the High Court admitted it. On appeal, the question of law articulated by the Supreme Court was: 'Is evidence procured by the guards in the course of and as a result of a domiciliary search, unauthorised by a search warrant, admissible in subsequent criminal proceedings?? ${ }^{36}$ The Court dismissed the appeal because the error did not warrant exclusion of the evidence. The majority (Kingsmill Moore J, Lavery and Budd JJ concurring) held that inclusion or exclusion of evidence was for the trial judge to decide at his or her discretion on a case-by-case basis. In their view, it would not be appropriate for the Supreme Court to set out a rule of either absolute inclusion or absolute exclusion.

The minority (Walsh J, Ó Dálaigh CJ concurring), however, distinguished between illegally obtained evidence and evidence obtained in breach of the accused's constitutional rights. According to Walsh J, evidence obtained in breach of a constitutional right 'assumes a far greater importance ${ }^{, 37}$ than if the breach was merely an illegality stopping short of a constitutional breach. He went on to say that 'protection of constitutional rights is a fundamental matter for all courts' and that the protection of the 'constitutional rights of the citizen is a duty superior to that of trying such citizen for a criminal offence'. ${ }^{38}$ Thus, the evidence should be excluded where it is:

obtained or procured by the State or its servants or agents as a result of a deliberate and conscious violation of the constitutional rights of the accused person where no extraordinary excusing circumstances exist, such as the imminent destruction of vital evidence or the need to rescue a victim in peril. ${ }^{39}$

While this case marked an important break with the common law inclusionary doctrine, and thus signalled the emergence of an Irish exclusionary rule, it was the more extreme position adopted by the minority in the case (led by Walsh J) which was to form the basis for the rule in years to come. Thus, in People (DPP) v Kenny, ${ }^{40}$ the Supreme Court accepted the minority decision of Walsh J in the earlier

\footnotetext{
${ }^{32}$ Foreword to B McMahon and W Binchy Irish Law of Torts (Abingdon: Professional Books, 1981).

${ }^{33}$ Letter from Walsh to Brennan, 28 February 1969, William J Brennan papers, Box II: 62, cited in Mac Cormaic, above $\mathrm{n}$ 27, p 106. 
decision of O'Brien as correct, thereby ending a period of uncertainty around the precise ratio of O'Brien, ${ }^{41}$ and 'affirm[ing] the exclusionary credentials of the Irish doctrine'. ${ }^{42}$ The implications were that evidence obtained or procured by the state as a result of a 'deliberate and conscious' violation of the constitutional rights of an accused person should be excluded where no extraordinary excusing circumstances exist. As the majority judgment of Finlay CJ made clear, the 'deliberate and conscious' phrase referred to the conduct of the gardaí as opposed to their state of mind, thereby significantly extending the scope of the rule. This was underpinned with a strong protectionist rationale and judicial approach which sought to optimise the protection of constitutional rights:

As between two alternative rules or principles governing the exclusion of evidence obtained as a result of the invasion of the personal rights of a citizen, the Court has, it seems to me, an obligation to choose the principle which is likely to provide a stronger and more effective defence and vindication of the right concerned. ${ }^{43}$

In adopting this position, the Court was acutely aware of the implications that exclusion of probative evidence may have on the criminal justice system. However, it held that no matter how important the detection of crime and conviction of perpetrators is, it 'cannot outweigh the unambiguously expressed constitutional obligations' on the Courts to 'defend and vindicate the personal rights of the citizen'. ${ }^{4}$

The new exclusionary rule established in Kenny joined several other decisions recognising new constitutional legal rights such as the right to free legal aid, the right to a reasonably expeditious trial, the right of reasonable access to a solicitor and the right to be presumed innocent, and this trend continued into the early 1990s. ${ }^{45}$ Indeed, the extent to which the courts were prepared to go in this regard was conspicuously revealed in the 1994 case of $Z v D P P^{46}$ where the Supreme Court held that in the event of a conflict between the constitutional right to a fair trial and the community's right to prosecute, the former must prevail. The pace of change was such that Hogan and Whyte, authors of the 1994 edition of JM Kelly's seminal text on Irish constitutional law, wondered whether the 'explosion of constitutional litigation' in the field of criminal procedure that had occurred since publication of the first edition in 1980 would 'admit of the possibility of coherent thematic treatment'. ${ }^{47}$ While there has undoubtedly been a certain retrenchment on the rights of the accused, and indeed personal rights more generally, from the mid-1990s onwards, the institutionalised nature of many of these due process rights has continued to act as an important counterpoint to shifts in the direction of crime control. As Vaughan and Kilcommins have written, 'the canopy of safeguards that has been created for those accused of crime has largely been marginalised and excluded in control talk... but it remains a formidable epistemic and practical force in Ireland'. ${ }^{48}$

While the above discussion has focused largely on constitutional jurisprudence since the 1960s, it is important to stress that the due process culture in Ireland is not confined to judicial doctrine. In so far as it has been examined in Ireland, commentators have tended to refer to it as an 'instinct', ${ }^{49}$

\footnotetext{
${ }^{41}$ Courts grappled with whether 'deliberate and conscious' referred to actual knowledge of the constitutional breach or simply a deliberate and conscious act that resulted in a constitutional breach. Compare, in particular, the outcomes in People (DPP) v Madden [1977] IR 336 and People (DPP) v Shaw [1982] IR 1.

${ }^{42}$ L Heffernan and U Ni Raifertaigh Evidence in Criminal Trials (Dublin: Bloomsbury, 2014) p 384.

${ }^{43}[1990] 2$ IR 110 , at $133-134$.

${ }^{44}$ Ibid.

${ }^{45}$ See State (Healy) v Donoghue [1976] IR 325 (right to legal aid); State (O'Connell) v Fawsitt [1986] IR 362 (right to an expeditious trial); DPP v Healy [1990] 2 IR 73 (right of reasonable access to a solicitor); O'Leary $v$ AG [1995] 1 IR 254 (right to be presumed innocent).

${ }^{46}$ [1994] IR 465.

${ }^{47} \mathrm{G}$ Hogan and G Whyte The Irish Constitution (Dublin: Butterworths, $3^{\text {rd }}$ edn, 1994) p xciii.

${ }^{48}$ Vaughan and Kilcommins, above n 23, p 98.

${ }^{49}$ Hamilton, above n 23, p 181. Interviewees spoke of judges' 'liberal instincts' and connected this with the legal training or education they would have received. 'The judges would have been in many cases practitioners from an early era and would still carry through a lot of the philosophy they were brought up with' (Interviewee 9).
} 
'philosophy, ${ }^{50}$ set of 'values' ${ }^{51}$ or 'culture ${ }^{52}$ more so than in the narrower sense of 'legal ideology'. ${ }^{53}$ Indeed, Vaughan and Kilcommins deploy the Bordieusian concept of 'habitus' to describe the phenomenon, a term which is generally understood to denote who you are as a person; your thoughts, tastes, beliefs, interests and general understanding of the world. ${ }^{54}$ This chimes with my own research and conversations with criminal law practitioners that tend to suggest a set of liberal sensitivities or 'cultural $\operatorname{logic}^{55}$ at work, such as the custom for defence solicitors not to go on to work for the Director of Public Prosecutions or for barristers not to congratulate a colleague on a conviction, only an acquittal. ${ }^{56}$ Practitioners with whom I spoke in 2009 also referenced a 'culture of fair play' among judges, derived from the philosophy they were brought up with, which can influence the manner in which they interpret legislation or run a trial. ${ }^{57}$ Most interestingly, one senior legal practitioner spoke of the way in which lawyers, like the judiciary, could dilute the effects of legislation where it conflicted with this more liberal legal culture, giving the example of inference provisions in the Criminal Justice Act $1984 .^{58}$

\section{3. $D P P \vee J C$}

The above account invites consideration of the decision in $J C$ and its impact on the existing legal culture: to what extent does its reversal of Kenny mark a definitive break with the past? Is the decision symptomatic of the demise of a due process legal culture in Ireland? How will it be received by trial judges? In many ways these questions are difficult to answer given that the decision is so recent and very few decisions have been handed down at an appellate level on the manner of its implementation. An additional, complicating factor is that, while the $J C$ decision is rightly understood as overturning the exclusionary rule as laid down in Kenny, a large part of the judgment is also taken up with the jurisdictional issue of whether the appeal was validly before the Court. It is worth dwelling on this point briefly given that it not only serves to underline the truly exceptional nature of the decision, but, as will be discussed, in terms of the backdrop to $J C$, it serves as an important 'bridge' between the internal and external dimensions of legal culture.

The respondent, JC, had been on trial for robbery before Judge Mary Ellen Ring and a jury at the Circuit Criminal Court. His arrest and questioning had taken place following the search of his premises on the basis of a warrant issued under s 29 of the Offences against the State Act 1939, and while in custody he had made several inculpatory statements. Before JC came to trial, the Supreme Court issued a decision in an unrelated case in which it declared s 29 (which allowed warrants to be issued by gardaí rather than an independent authority) unconstitutional. ${ }^{59}$ The effect of this finding was that at the time that JC made the inculpatory statements, he was in unlawful custody. Judge Mary Ellen Ring, correctly following the precedent in Kenny, excluded the statement evidence and directed the accused's acquittal. The DPP appealed the decision to the Supreme Court under s 23 of the Criminal Procedure Act 2010, a

\footnotetext{
${ }^{50}$ Ibid.

${ }^{51}$ O Doyle and E Feldman 'Constitutional law' (2015) Annual Review of Irish Law 156 at 221 (discussing the impact of JC): 'the Kenny values have been so internalised by the legal profession, from which trial judges are drawn, that [the inclusionary] test will be applied strictly'.

${ }^{52}$ Ibid. 'There is no textual justification in the Constitution to treat criminal process rights - largely unenumerated - with greater seriousness than other textual guarantees. Nevertheless, this attitude is a significant feature of Irish constitutional culture'.

${ }^{53}$ Although ideology may be part of this broader culture. See Kilcommins, above n 23, at 328, 338, where he refers to 'the liberal ideology of legalism and constitutionalism' in Ireland.

${ }^{54}$ Vaughan and Kilcommins, above n 23, pp 11, 18 and passim.

${ }^{55} \mathrm{~S}$ Field 'Finding or imposing coherence? Comparing national cultures of youth justice' in Nelken, above n 10 , p 306.

${ }^{56}$ I am grateful to participants in the Criminal Law Forum, Maynooth University, Maynooth, Co Kildare, 14 April 2018 for this observation.

${ }^{57}$ Hamilton, above n 23, p 181.

${ }^{58}$ See further Hamilton, above n 23, p 182.

${ }^{59}$ Damache v DPP [2012] 2 IR 266.
} 
novel provision allowing the DPP to appeal an acquittal to the Supreme Court in the case of a ruling 'which erroneously excluded compelling evidence'. Notwithstanding the Supreme Court unanimously accepting that the law was correctly applied, it allowed the appeal on the basis that Kenny itself was erroneously decided. As Daly asserts, this 'required significant linguistic acrobatics' from the Supreme Court to justify the appeal, and even more 'questionable' behaviour from the DPP in pursuing it under this particular section. ${ }^{60}$ It is worth noting that this was the first time this provision had been used and its deployment in $J C$, 'essentially with a view to having Kenny overruled', ${ }^{61}$ has been heavily criticised. ${ }^{62}$

To focus in on the issue decided in the case it is helpful to cite the following extracts from the judgment of Clarke J, which clearly sets out four key elements to the new rule:

1 Where objection is taken to the admissibility of evidence on the grounds that it was taken in circumstances of unconstitutionality, the onus remains on the prosecution to establish either:

(a) that the evidence was not gathered in circumstances of unconstitutionality; or

(b) that, if it was, it remains appropriate for the court to nonetheless admit the evidence.

2 Where evidence is taken in deliberate and conscious violation of constitutional rights then the evidence should be excluded save in those exceptional circumstances considered in the existing jurisprudence. In this context, deliberate and conscious refers to knowledge of the unconstitutionality of the taking of the relevant evidence rather than applying to the acts concerned.

3 The assessment as to whether evidence was taken in deliberate and conscious violation of constitutional rights requires an analysis of the conduct and state of mind not only of the individual who actually gathered the evidence concerned but also of any other senior official or officials within the investigating or enforcement authority concerned who are involved either in that decision or in decisions of that type generally or in putting in place policies concerning evidence gathering of the type concerned.

4 Where evidence is taken in circumstances of unconstitutionality but where the prosecution establishes that same was not conscious and deliberate in the sense previously appearing, then a presumption against the admission of the relevant evidence arises. Such evidence should be admitted where the prosecution establishes that the evidence was obtained in circumstances where any breach of rights was due to inadvertence or derives from subsequent legal developments.

As can be seen from the judgment, following $J C$ 'deliberate and conscious' is reinterpreted as knowledge of the unconstitutionality of the taking of the relevant evidence rather than applying to the physical action of the relevant investigating officer, thus providing a much more uncertain foundation for exclusion of evidence obtained unconstitutionally. As Doyle and Feldman have pointed out, under the old Kenny rule, it was difficult to imagine circumstances in which an officer of the state could carry out a search other than deliberately and consciously: 'perhaps a sleepwalking Garda or a Garda who falls out of a hot air balloon?'. ${ }^{63}$ Combined with this is the subjection of the exclusionary rule to the vagaries of 'inadvertent' state conduct, arguably the major departure involved in the decision.

Certainly, this was the view of Hardiman J, one of the minority judges in JC, who described the introduction of an 'inadvertence' exception 'as a gratuitous writing down of the respect due to the

\footnotetext{
${ }^{60} \mathrm{Y}$ Daly 'Overruling the protectionist exclusionary rule: DPP v JC' (2015) 19(4) International Journal of Evidence and Proof 270 at $275-276$.

${ }^{61}$ D Walsh Criminal Procedure (Dublin: Round Hall, 2018) [12-115].

${ }^{62}$ See, for example, Walsh, above n 61, paras [26-256]-[26-284]; Daly, above n 60, at 275-276; Fennelly, above n 1.

${ }^{63}$ Doyle and Feldman, above n 51, at 221.
} 
Constitution' and 'an absolutely retrograde step which I deeply deplore'. ${ }^{64}$ He regarded Kenny as 'one of the monuments of the constitutional jurisprudence of independent Ireland' and a case he specifically had in mind when he undertook his oath to uphold the Constitution. ${ }^{65}$ For him, therefore, the decision of the majority in $J C$ represented a 'revolution in principle ${ }^{66}$ and 'a major step in the disengagement of this Court from the rights-oriented jurisprudence of our predecessors' ${ }^{67}$ Though less strident in its language, McKechnie J's dissent made similar points about the significance of the protectionist principles underlying the Kenny decision, not least in terms of constitutional rights having tangible effects for citizens:

I remain unwavering in my stance that the primacy of rights basis, as offered for the rule in Kenny, is correct: as I do in respect of the rule itself, for if guaranteed fundamental rights, as specified in the Constitution are to be really meaningful in practical life, then that approach is justified. $^{68}$

On the other side of the balance sheet, however, there are important nuances in the decision in JC which should not be overlooked in any assessment of its impact. One concerns the scope of the new rule given that O'Donnell J specified that the decision in JC applies only in the context of search warrants, while Clarke J was not quite as restrictive. ${ }^{69}$ The second concerns the range and type of behaviour encompassed by the 'inadvertence' standard. While the new rule ensures that evidence obtained in inadvertent breach of constitutional rights may be admitted at trial, the case also introduces a rebuttable presumption against the admission of evidence obtained in reckless or grossly negligent breach of constitutional rights. The operation of the inadvertence exception is therefore mitigated through the insertion of 'a negligence-based standard for assessing whether there had been a deliberate and conscious violation of constitutional rights', ${ }^{70}$ prompting some authors to argue that the retreat from existing jurisprudence is actually quite limited. ${ }^{71}$ While to some degree this awaits clarification from the appellate courts, empirical work on the test's implementation to date indicates that the rule is currently being applied in a predominantly inclusionary manner by trial judges and that the safeguards set out in $J C$ appear to do little to protect against wilful abuse of constitutional rights. ${ }^{72}$ Factors identified as relevant by practitioners in this regard include the wellestablished difficulties of establishing something that is peculiarly within the knowledge of the officer in question, or, as one interviewee put it, 'showing a negative'. ${ }^{73}$ The other important consideration raised by practitioners, given that exclusion is now predicated on findings of recklessness or gross negligence, is courtroom dynamics and the risks attendant upon effectively accusing members of the gardaí of mala fides. ${ }^{74}$ Finally, in terms of impact, this study also raises significant concerns about the knock-on effect of JC in 'sucking the content' from other due process rights such as the right to privacy, as well as the negative impact on policing and prosecutorial standards more broadly. ${ }^{75}$

\footnotetext{
${ }^{64} D P P$ v JC, above n 3, Hardiman J [Introduction].

${ }^{65} \mathrm{Ibid}$.

${ }^{66} \mathrm{DPP} v \mathrm{JC}$, above n 3, Hardiman J, para 134.

${ }^{67} D P P$ v JC, above n 3, Hardiman J [Introduction].

${ }^{68} D P P$ v JC, above n 3, McKechnie J, para 252.

${ }^{69}$ It is noteworthy that in DPP $v$ Doyle [2017] IESC 1 MacMenamin J contemplated the application of the rule to exclude evidence obtained in relation to a potential breach of one's constitutional right to a lawyer during questioning.

${ }^{70} \mathrm{G}$ Hogan 'Mr Justice Brian Walsh: the legacy of experiment and the triumph of judicial imagination' (2017) 57 Irish Jurist 1 , at fn 53 .

${ }^{71}$ See in particular Leon and Ward, above $\mathrm{n} 8$.

${ }^{72}$ Hamilton (with Gough), above n 26.

${ }^{73}$ Ibid, pp 57-58.

${ }^{74}$ Hamilton (with Gough), above n 26, pp 38-39. On courtroom dynamics, see further R Young 'Exploring the boundaries of the criminal courtroom workgroup' (2013) 42 Common Law World Review 203.

${ }^{75}$ Ibid, pp 43-46, 46-48.
} 


\section{4. $J C$ and legal culture}

While these issues remain to be teased out by the appellate courts, the significance of $J C$, even on a symbolic level, cannot be denied. There can be little doubt that Brian Walsh, Cearbhail O'Dalaigh and the other visionaries of the 1960s, 70s and 80s would recoil from a finding that the principles elaborated in Kenny were, in O'Donnell J'.s words, 'plainly wrong. ${ }^{76}$ Indeed, as noted, the decision itself revealed some deep ideological divisions within the Irish Supreme Court as it was then constituted, signalling a clear rift between those still moored to the protectionism of the Kenny decision and those of a more reformist bent. The uncompromising and even emotional tenor of the language deployed by the minority in $J C$-'a monument of Irish constitutional jurisprudence', 'central bulwark of freedom in this country', deplorable and 'utterly retrograde' step - clearly reflects their disbelief that Kenny and its values are being swept aside. In understanding this significant shift in Irish legal culture, this section aims to deploy Friedman's legal culture concept, including his distinction between the internal legal culture of professionals working in the system from the external legal culture of citizens interacting with the system.

\section{(a) External legal culture}

Turning first to the external dimension of legal culture, it is not difficult to find evidence of political dissatisfaction with the exclusionary rule as articulated in Kenny. One of the most vocal critics of the rule was former Minister for Justice, Michael McDowell, who in 2006 argued that the rule 'leads to the unintended outcome of accused persons regularly getting away with crimes on a technicality. ${ }^{77}$ McDowell established an expert group known as the Balance in Criminal Law Group, tasked with the examination of a range of issues including the operation of the exclusionary rule, the right to silence, the admission of character evidence, and permitting prosecution appeals. The aim was to strike a fair balance between the rights of the community and victims of crime on the one hand and the traditional rights of an accused on the other. The Group, which reported in 2007, took issue among other things with the rule's perceived unfairness in allowing 'technical errors' to lead to acquittals and recommended a judicial discretion to admit evidence having regard to the circumstances of the case. ${ }^{78}$ Their preference for judicial discretion in this area was notably predicated on the need to have 'regard to the totality of the circumstances and in particular the rights of the victim'. ${ }^{79}$ Interestingly, given the potential constitutional infirmities that would be associated with any legislative solution, they suggested that the (then) newly introduced provisions of the Criminal Justice Act 2006 providing for 'without prejudice' prosecution appeals, may provide the Supreme Court with an opportunity, in an appropriate case, of revisiting its case law and moving towards the discretionary approach. As Fennell has remarked, this is an interesting example of court-legislature dialogue that appears 'somewhat less subtle than instances of earlier such detected influences on judicial decisions' ${ }^{80}$ It is no coincidence, therefore, that in the final result reform of the rule did come through a prosecution appeal, but of the 'with prejudice' variety, introduced in 2010 as a result of another of the Balance in Criminal Law Group's recommendations. ${ }^{81}$ The controversial decision taken by the DPP to bring a 'with prejudice' appeal in the JC case, scathingly described as a 'contrivance' by the minority judges, ${ }^{82}$ therefore forms an important link with external legal culture and its longstanding dissatisfaction with the law on unconstitutionally obtained evidence as it then stood.

\footnotetext{
${ }^{76}$ DPP $v$ JC, above n 3, O’Donnell J, para 115.

${ }^{77} \mathrm{M}$ McDowell 'Rebalancing criminal justice - remarks by Tánaiste in Limerick', 20 October 2006, available at http://www. justice.ie/en/JELR/Pages/Speech-rebalancing-criminal-justice (last accessed 25 February 2021).

${ }^{78}$ Balance in Criminal Law Review Group (Dublin: Stationery Office, 2007), available at http://www.justice.ie/en/JELR/ Pages/Balance-in-criminal-law-report (last accessed 25 February 2021). The exclusionary rule is discussed on pp 147-166.

${ }^{79}$ Ibid, p 165.

${ }^{80} \mathrm{C}$ Fennell The Law of Evidence in Ireland (Dublin: Bloomsbury, $3^{\text {rd }}$ edn, 2009) para 4.106.

${ }^{81}$ Criminal Procedure Act 2010, s 23, discussed above.

${ }^{82}$ DPP v JC, above n 3, McKechnie J, para 82.
} 
The criticisms of the Review Group, combined with trenchant attacks on the rule from politicians ${ }^{83}$ and the Director of Public Prosecutions, ${ }^{84}$ lend support to the view of $J C$ as an example of law and order concerns amongst the wider public 'catching up' with the Irish Supreme Court's due process oriented jurisprudence. ${ }^{85}$ As a growing number of scholars now attest, the politicisation of crime and growth in popular punitiveness identified by Garland and others ${ }^{86}$ has not overlooked the field of procedural rights, ${ }^{87}$ and the winds of change that have swept other western jurisdictions in recent decades are also evident in Ireland. In this regard, Walsh has counted 27 major criminal justice enactments in Ireland enhancing the powers of the police and the prosecution between the seminal Criminal Justice Act 1984 and a watershed Criminal Justice Bill in $2005 .^{88}$ The same author noted:

[i]ncreasingly guilt will be determined by executive processes in the closed secrecy of the police station rather than by judicial processes in the public transparency of the courtroom. Judicial territory is being ceded to the police to achieve a further streamlining and bureaucratisation of the criminal process. $^{89}$

While this process has had a long gestation, ${ }^{90}$ several of the most significant reforms can be traced back to the period following the fatal shooting of journalist Veronica Guerin, ${ }^{91}$ including reform of the law on bail, civil forfeiture of crime proceeds, and the erosion of the right to silence. ${ }^{92}$ From at

\footnotetext{
${ }^{83}$ In addition to Michael McDowell's comments as former Minister for Justice, see Labour Councillor, Richard Humphreys 'Miscarriage of justice as guilty get off on a technicality' (Sunday Independent, 28 July 2013), available at https://www.independent.ie/opinion/analysis/richard-humphreys-miscarriage-of-justice-as-guilty-get-off-on-technicality-29453976.html (last accessed 25 February 2021).

${ }^{84}$ James Hamilton, former Director of Public Prosecutions described the exclusionary rule as 'a classic example of what is called "cutting off your nose to spite your face"': J Hamilton 'Opening remarks $-7^{\text {th }}$ annual prosecutors' conference', Dublin Castle Conference Centre, 13 May 2006, available at https://www.dppireland.ie/app/uploads/2019/03/DIRECTOR__Opening_Remarks.pdf (last accessed 25th February 2021).

${ }^{85}$ This is the view taken by Dimitri Giannopoulos Improperly Obtained Evidence in Anglo-American and Continental Law (Oxford: Hart Publishing, 2019) p 237.

${ }^{86}$ Garland, above n 21; see also J Pratt et al (eds) The New Punitiveness (2005). Kilcommins, above $\mathrm{n} 23$, at 327, gives a neat summary of these arguments, as they relate to the field of procedural rights, as follows: 'from sovereign to disciplinary power (Foucault, 1991); due process to crime control (Packer, 1968); modernity to late modernity/postmodernity (Lea, 2002); penal welfarism to a culture of control (Garland, 2001); a constitutional state to a security state (Hudson, 2003: 170); individualised justice to actuarial justice (Feeley and Simon, 1994); an inclusive to an exclusive society (Young, 1999); civilising to decivilising trends (Pratt, 1998); correctionalist criminology to criminologies of everyday life (Garland and Sparks, 2000); liberalism to communitarianism/neo-liberalism/neoconservatism (O’Malley, 1999); and Rule of Law to Rule by Law modes of governance (Dyzenhaus, 2006)'.

${ }^{87}$ Several authors have drawn attention to David Garland's failure to consider due process rights in his study of the development of a culture of control. See, for example, L Campbell 'The culture of control in Ireland: theorising recent developments in criminal justice' (2008) 1 Web Journal of Current Legal Issues (internet), available at http://webjcli.ncl.ac.uk/ 2008/issue1/campbell1.html (last accessed 25 February 2021); S Kilcommins et al Crime, Punishment and the Search for Order in Ireland (Dublin: Institute of Public Administration, 2004) p $142 \mathrm{ff}$ and H Quirk 'Criminal evidence and the culture of control', DCU criminal evidence and procedure workshop, 12 October 2018. An early observer of the links between procedural rights for defendants and harsher punishments is Michael Tonry 'Symbol, substance and severity in western penal policies' (2001) 3(4) Punishment \& Society 517.

${ }^{88} \mathrm{D}$ Walsh 'The Criminal Justice Bill: completing a crime control model of criminal justice?'. Criminal Justice Bill 2004: Implications for Human Rights and Legal Practice, 20 April 2005, Trinity College Dublin.

${ }^{89} \mathrm{D}$ Walsh 'Police powers in the Criminal Justice Act 2006: the triumph of executive convenience over judicial checks and balances' Thomson Round Hall Criminal Law Conference, Royal College of Surgeons, 25 November 2006.

${ }^{90}$ See, for example, Fennell, above n 80, para 2.53, where she writes that Downes and Morgan's comments on the decline of the post-war bipartisan consensus on the politics of law and order in the UK 'could with equal measure be made of Ireland'. See D Downes and R Morgan 'Dumping the "hostages to fortune?" The politics of law and order in post-war Britain' in M Maguire et al (eds) The Oxford Handbook of Criminology (Oxford: Oxford University Press, $2^{\text {nd }}$ edn, 1997).

${ }^{91}$ Veronica Guerin was an Irish crime reporter who was murdered in June 1996 by an organised crime gang whose activities she was investigating.

${ }^{92}$ For a discussion of the reforms during this period and their impact see Hamilton, above n 24, ch 5 .
} 
least this point in the mid-1990s, a 'tooling up ${ }^{\text {,93 }}$ of the Irish state is evident, concerning, for example, an expansion of powers of search, seizure and detention; restrictions on the right to silence and the right to privacy; and in the expansion in the range of hybrid offences which, at the option of the prosecutor, deny the right of an accused to a jury trial. Similarly, surveying the Irish criminal justice landscape in recent decades, Daly and Jackson write of a 'decided shift in the direction of crime control... prompted by pressing domestic needs to combat subversion and gangland crime and bolstered by a global rhetoric which has subjugated defence interests in favour of victims' interests. ${ }^{94}$ Indeed, Kilcommins and Vaughan ${ }^{95}$ go even further in their description of Ireland as a 'lodestar for other jurisdictions' in terms of the devaluation of due process values. The moves towards consequentialism and a more results-oriented logic in the judgments of the majority in $J C$ can therefore only be understood in the context of the wider debate on the exclusionary rule and due process rights more broadly.

\section{(b) Internal legal culture}

This political unease with the exclusionary rule was also reflected in the internal legal culture, with several superior court decisions preceding the JC decision in 2015 arguably in tension with the protectionist stance adopted by Finlay CJ in Kenny. A good example of this is the very narrow approach taken by the courts to the requirement of a causative link between the violation of the rights and the obtaining of the evidence. ${ }^{96}$ This is particularly evident in cases alleging breaches of the constitutional right of reasonable access to a solicitor ${ }^{97}$ such as People (DPP) $v$ O'Brien. $^{98}$ In that case both the Court of Criminal Appeal and the Supreme Court held, in line with the trial judge's determination at trial, that there had been a deliberate and conscious breach of the accused's constitutional right to pre-trial legal advice (knowingly contacting a particular solicitor who would be significantly delayed in attending at the garda station) and that the statements made by him prior to the arrival of his solicitor ought therefore to be excluded. Despite this, they went on to find that statements made after the accused had consulted with his legal advisor were admissible as any breach of rights had been cured or remedied at that stage. As Daly has argued, this ignores both the potential for an ongoing causative link between the breach and the statements made, even after consultation with a solicitor, and the positive duty on the courts, outlined in earlier precedents such as Trimbole and Kenny, to defend and vindicate the rights of all citizens. ${ }^{99}$ A highly sceptical note was also struck by the Court of Criminal Appeal in DPP $v$ Mallon, ${ }^{100}$ where O'Donnell $\mathrm{J}$ questioned the underlying assumption of O'Brien, namely that a defect in the search warrant deprived it of authority, and confirmed the distinction developed in Balfe ${ }^{101}$ between patent and latent defects in the search warrants. Fennell notes the similarity in tone between Mallon and JC and describes Mallon as 'offering a sneak preview or dress rehearsal of the decision in JC itself. ${ }^{102}$ This trend culminated in DPP (Walsh) $v$ Cash ${ }^{103}$ which seemed potentially to offer the Supreme Court an opportunity to revisit and/or reinterpret the exclusionary rule, and

\footnotetext{
${ }^{93}$ See Kilcommins, above n 23, at 237.

${ }^{94} \mathrm{Y}$ Daly and J Jackson 'The criminal justice process: from questioning to trial' in D Healy et al (eds) The Routledge Handbook of Irish Criminology (London: Routledge, 2016) p 293.

${ }^{95}$ S Kilcommins and B Vaughan 'A perpetual state of emergency: subverting the rule of law in Ireland' (2004) 35 Cambrian Law Review 55.

${ }^{96}$ Walsh v O Buachalla [1991] 1 IR 56.

${ }^{97} \mathrm{~A}$ constitutional right of access to a solicitor prior to questioning has now been recognised by the Irish Supreme Court in the joined cases of DPP $v$ Gormley and DPP $v$ White [2014] 2 IR 591.

${ }^{98}$ [2005] 2 IR 206. See also DPP v Buck [2002] 2 IR 268.

${ }^{99}$ See Y Daly 'Does the Buck stop here? An examination of the pre-trial right to legal advice in the light of O'Brien $v$ DPP' (2006) 28 Dublin University Law Journal 296.

${ }^{100}$ [2011] IECCA 29.

${ }^{101}$ People $(D P P) v$ Balfe [1998] 4 IR 50. As Daly, above $\mathrm{n} 60$, notes at 278, since Balfe, the situation in relation to errors in search warrants could be stated as: 'O'Brien allowing for admission of the evidence where there is an error on the face of the warrant and Kenny leading to exclusion where there is a deficiency in the authorisation of the warrant or its legal value'.

${ }^{102} \mathrm{C}$ Fennell The Law of Evidence in Ireland (Dublin: Bloomsbury, $4^{\text {th }}$ edn, 2020) para 8.124.

${ }^{103}$ [2007] IEHC 108, [2010] IESC 1.
} 
which in terms of tone at least, forms an important prelude to $J C .{ }^{104}$ In the event, the Court, much to the disappointment of the DPP, ${ }^{105}$ sidestepped discussion of the rule on its merits, but narrowed its application through its finding that it did not apply to evidence grounding a decision to arrest a suspect. ${ }^{106}$ In the course of his judgment in the High Court, Charleton J took the opportunity to review the case law since O'Brien, delivering an obiter, but nonetheless withering, attack on the exclusionary rule. In his view, 'a rule which remorselessly excludes evidence obtained through an illegality occurring by a mistake does not commend itself to the proper ordering of society which is the purpose of the criminal law. ${ }^{107}$ He goes on to propound a 'balancing of interests' between 'society and the accused' but importantly also those of the victim.

Another key part of the backcloth to the JC decision is the Supreme Court case of People (DPP) $v$ Damache. ${ }^{108}$ This decision, handed down in February 2014, declared unconstitutional s 29(1) of the Offences Against the State Act $1939,{ }^{109}$ which allowed for search warrants to be issued by senior members of the gardaí rather than a judge or peace commissioner (so-called 'self-service warrants'). ${ }^{10}$ The Supreme Court held that s 29(1) was 'repugnant to the Constitution as it permitted a search of the appellant's home contrary to the Constitution, on foot of a warrant which was not issued by an independent person'. ${ }^{111}$ The result of the unconstitutionality was that the gardaí were trespassers in $\mathrm{Mr}$ Damache's home, thereby casting doubt on the admissibility of the mobile phone evidence obtained because of the warrant. Beyond the case itself, the decision had implications for a number of other cases where evidence had been obtained pursuant to s 29(1) warrants, opening up an 'appalling vista of criminals who had been lawfully and rightfully convicted now walking free due to a "technicality"' ${ }^{112}$ In addition, many serious cases pending before the Circuit, Central and Special Criminal Courts collapsed or were stopped at the instigation of the courts or of the state. ${ }^{113}$ All of this brought, 'a new focus and urgency to the debate on the exclusionary rule,,${ }^{114}$ highlighting what Hogan has described as its many 'unanticipated effects' in practice. ${ }^{115}$ Indeed, Damache is directly implicated in the facts of the JC decision itself, given that the search warrant authorising the search of JC's dwelling was found to be invalid as a consequence of the finding in Damache. As with the external legal culture, however, judicial criticism of the exclusionary rule is best understood as part of a broader drift towards an increasingly results-oriented logic within the internal legal culture in Ireland. In

\footnotetext{
${ }^{104}$ It is noteworthy that Caroline Fennell argues that the decision in Curtin v Dáil Eireann [2006] 2 IR 556 also provides 'early evidence that the reign of the exclusionary rule in the Irish criminal process might be on the wane': Fennell, above $n$ 102 , para 8.106 .

${ }^{105}$ In submissions before the Supreme Court in JC the Director of Public Prosecutions (DPP) appeared disappointed that the Court had not taken the opportunity presented by Cash to review the Kenny rule: DPP v JC [2015] IESC 31 per McKechnie J at para 96.

${ }^{106}$ Unlawfully retained DNA evidence (fingerprints) had been used to ground reasonable suspicion for a lawful arrest. As Daly observes, this position is at odds with the protectionist stance outlined in Kenny: 'One would have thought that, in order to give effect to the protectionist stance adopted in Kenny, evidence obtained (or retained) in violation of constitutional rights ought not to be allowed as the basis for a lawful arrest or, if relied upon to ground an arrest, should render that arrest unconstitutional, and any evidence subsequently obtained ought to be excluded accordingly'. See Y Daly 'Exclusion of evidence: DPP (Walsh) v Cash' (2011) 15 International Journal of Evidence \& Proof 62 at 67.

${ }^{107}$ [2007] IEHC 108 at para 65.

${ }^{108}$ [2012] 2 IR 266.

${ }^{109}$ On the Offences against the State Act 1939, see further M Coen (ed) The Offences Against the State Act 1939 at 80: A Model Counter-Terrorism Act? (Oxford: Hart Publishing, 2021).

${ }^{110}$ See further on this decision, Y Daly 'Independent issuing of search warrants: Damache v DPP' (2013) 17(1) The International Journal of Evidence \& Proof 114.

${ }^{111}$ [2012] IESC 11 at para 59.

${ }^{112}$ M Lynam 'The Damache case and potential "catastrophic consequences"', paper delivered at the IHRC \& Law Society 10th Annual Human Rights Conference, 13 October 2012, available at https://www.ihrec.ie/app/uploads/download/pdf/ mr_mark_lynam_bl_ihrc_law_society_10th_annual_human_rights_conference_13_october_2012.pdf (last accessed 25 February 2021).

${ }^{113}$ Ibid.

${ }^{114}$ O Keenan 'Exclusive club' (2012) October Gazette of the Incorporated Law Society at 32.

${ }^{115}$ Hogan, above n 70, at 12 .
} 
this regard, Daly and Jackson ${ }^{116}$ write of judicial acceptance of, and deference towards, legislative measures interfering with individual rights, including acceptance of the normalisation of increasing police powers. Similarly, Hogan, reflecting on the legacy of former Supreme Court judge Brian Walsh, describes a change in what he terms the 'prevailing constitutional Zeitgeist ${ }^{117}$ in recent years, citing by way of illustration the narrowing of the grounds for habeas corpus. ${ }^{118}$

Of course, in revealing the internal cultural dimensions motivating the reform in $J C$, there is also much to be gained from a close parsing of the judgments themselves. As compared with Charleton J's strident views on the exclusionary rule in Cash, for example, there is less than might be expected regarding the rights of victims and the need to strike a 'balance' between the right of the community and the accused. That said, two of the majority judges, Clarke and McMenamin JJ, explicitly reference the rights of victims to ensure that those who commit crimes against them are brought to justice. MacMenamin $J$ in particular was keen to acknowledge the diverse range of interests at play in the criminal process, beyond the state-accused dichotomy:

[Rights] are not simply those of the State and the accused, but rather encompass a broader range of interests and rights, including the right of the community to have crime prosecuted when offences have been committed, and the interests of victims of crime. ${ }^{119}$

In similar, but not identical, vein, O’Donnell J appears more concerned with the societal cost which can come from the exclusion of probative evidence and the knock-on effects of such exclusion on public confidence in the legal system. He noted:

the exclusion of evidence of undoubted cogency extracts a significant price in terms of the capacity of the court to perform its primary function [to determine contested matters to a requisite standard of proof], and accordingly in terms of confidence in, and respect for, the legal system. Such a course must always be justified by considerations sufficient to pay that price. ${ }^{120}$

Despite the clear weather eye in the majority judgments towards the rights of victims and public confidence in the justice system, $J C$ can also be approached technocratically, as a long overdue correction in Irish evidentiary jurisprudence. This more doctrinal reading derives from the inconsistencies between the two leading decisions in O'Brien and Kenny, which, as noted by the Balance in Criminal Law Review Group:

can be demonstrated by the fact that when one applies the principles set out in Kenny to the facts in O'Brien, a different outcome would result. The members of the Garda Síochána in O'Brien 'consciously and deliberately' searched the house of the accused and the fact that they were unaware that the warrant related to different premises was not something to which, on the basis of Kenny, the courts could have regard. ${ }^{121}$

Doyle and Feldman advance this argument in even stronger terms, arguing that Kenny effectively overruled O'Brien, but without making this explicit. From their perspective, the reformulated test therefore represents a significant improvement in the quality and transparency of the law in this area, returning the words 'deliberate and conscious' to their ordinary meaning. ${ }^{122}$ These views are largely shared by

\footnotetext{
${ }^{116}$ Above, n 94, p 292.

${ }^{117}$ Hogan, above $\mathrm{n} 70$, at 13 .

${ }^{118}$ The remedy of habeas corpus is available to all those who believe they are being detained unlawfully under Art 40.4.2 of the Irish Constitution. To illustrate the point, Hogan gives the example of Ryan v Governor of Midland Prison [2014] IESC 54.

${ }^{119} D P P \vee J C$, above n 3, MacMenamin J at para 73.

${ }^{120} \mathrm{DPP} v \mathrm{JC}$, above $\mathrm{n} 3$, O’Donnell $\mathrm{J}$ at para 4.

${ }^{121}$ Balance in Criminal Law Review Group, above n 78, p 158.

${ }^{122}$ Doyle and Feldman, above n 51, at 221. Hogan, above n 70, also noted that uncertainty as to the precise ratio of the original decision in The People (Attorney General) v O'Brien [1965] IR 142 has been the subject of endless debate: citing The
} 
the majority in JC, with Clarke J opining, 'it is impossible, therefore, to come to any conclusion other than that, if Kenny correctly states the legal position, O'Brien was wrongly decided'. ${ }^{123}$ In his judgment, O'Donnell J also argues strongly from a position of ensuring the integrity and internal coherence of Irish law in this area: 'the issue for this Court is ... not whether the exclusionary rule in Kenny is inconvenient at a practical level, but rather whether as a matter of constitutional law it is right'. ${ }^{124}$

\section{Implications}

Returning to Friedman's conception of legal culture, it will be recalled that for him it was external social forces that shape its direction and content, rather than the internal evolution of legal tradition. ${ }^{125}$ The case of the exclusionary rule in Ireland in many ways appears to affirm this view, with strong demands for reform of the rule dating from at least the Balance in Criminal Law Review Group in 2007 and judicial decisions reflecting the new positioning of the victim as a 'powerful motif. ${ }^{126}$ These demands, as we have seen, went beyond the 'normal' level of political influence on court jurisprudence, and as discussed above, the decision of the DPP to move a 'with prejudice' appeal in $J C$ forms an important link with external legal culture and its longstanding dissatisfaction with the law on unconstitutionally obtained evidence. Considered against the already substantial literature on the emergence of a 'hardline agenda' ${ }^{\prime 27}$ on criminal justice in Ireland, it is tempting to adopt a reading of $J C$ as a kind of metaphorical 'day of reckoning' for an aspect of Irish legal culture that had continued to provide strong due process protections to accused persons, precipitated perhaps by the Damache litigation, and the 'potentially catastrophic consequences ${ }^{128}$ with which it became associated. As against this, there is the view of $J C$ as a correction in doctrinal terms given the fact that a core factor in the majority's decision was their conclusion that the Supreme Court in Kenny had erred in its interpretation of the rule as laid down in O'Brien. There is a superficial attractiveness also to this argument, given the tensions between the seminal decision of O'Brien and Kenny noted above and the uncertainty over the precise ratio of O'Brien. Yet, as Walsh has argued, this is to ignore the possibility that the Supreme Court in Kenny was merely taking the opportunity to clarify the law following a degree of vacillation on the issue post O'Brien. ${ }^{129}$ As he goes on to argue, moreover, the majority's true intentions in $J C$ are perhaps revealed through their decision to effectively overrule O'Brien and formulate a new exclusionary rule rather than 'restoring' the law to the position as laid down in O'Brien. ${ }^{130}$ That said, it would be churlish not to acknowledge the clear efforts of the Supreme Court majority to mitigate the harshness of the $J C$ decision. First, unlike other common law jurisdictions, they did not leave a balance to be worked out by judges on a case-by-case basis, but elaborated a new rule at some length, including a presumption against the admissibility of evidence obtained unconstitutionally. Secondly, they go beyond O'Brien and the exclusion of evidence obtained in 'conscious and deliberate' breach of the Constitution, to include also evidence obtained in reckless or grossly negligent disregard of the Constitution. Thirdly, this applies not only to the individual officer in question but also any senior officials involved in the decision. Finally, and crucially, the judgment of Clarke J signalled an intention to address any tendency towards over-inclusiveness

People (Director of Public Prosecutions) $v$ Shaw [1982] IR 1 and The People (Director of Public Prosecutions) $v$ Lynch [1982] IR 64 and P O'Connor 'The admissibility of unconstitutionally obtained evidence in Irish law' (1982) 17 Irish Jurist 257.

${ }^{123} D P P$ v JC, above n 3, Clarke J at para 1.3.

${ }^{124} D P P$ v JC, above n 3, O’Donnell J at para 8.

${ }^{125} \mathrm{D}$ Nelken 'Comparative legal research and legal culture: facts, approaches, and values' (2016) 12 Annual Review of Law \& Social Sciences 45 at 47.

${ }^{126}$ A Bottoms 'Neglected features of contemporary penal systems' in D Garland and P Young (eds) Power To Punish (London: Heinemann Educational, 1983) p 166.

${ }^{127}$ O'Mahony, above n 28, p 188.

${ }^{128}$ Lynam, above n 112.

${ }^{129}$ Walsh, above n 61, para [12.120].

${ }^{130}$ Ibid, para [12.133]. 
among trial judges through vigorous appellate review. ${ }^{131}$ Given the broadly inclusionary trend suggested by preliminary empirical research in this area, the willingness of the courts to exercise their supervisory power in this regard may well prove crucial in ensuring the test is applied as intended. ${ }^{132}$

Perhaps the best reading of $J C$ is therefore to acknowledge the crucial role of social pressures (external legal culture) in bringing about change, mediated by an internal legal culture that is itself riven with tensions and inconsistencies. ${ }^{133}$ While long in evidence before and after the decision in Kenny, it was only when external forces appeared to capitalise upon these tensions (somewhat ironically as a result of a decision, Damache, with a strong due process rationale) that change eventually occurred. On this view, Ireland's liberal, due process oriented legal culture represents a kind of a 'lag', or 'restraint' on popular sentiment, but one that is far from static or the dope of structural forces. Internal legal culture is, moreover, as Ginsburg reminds us, 'also partly a wild card, not capable of mechanistic analysis'. ${ }^{134}$ This is important in the Irish context where recent decisions, including the decision in Damache discussed above, do not unproblematically reflect popular sentiment on criminal justice and arguably demonstrate the continued resonance of a rights-based orientation. ${ }^{135}$ The fate of the exclusionary rule in Ireland may therefore continue to be intertwined with what Kilcommins ${ }^{136}$ terms the 'institutional and epistemic authority' of legal and constitutional liberalism in Ireland, as legal actors seek ideational resources from elsewhere to resist change.

Thus far we have considered the values, attitudes and beliefs in play in discussion of the Irish exclusionary rule largely on their own terms. Yet, with the onset of political, economic and legal globalisation, there are ever more opportunities to define one's own legal culture in relation to legal cultures elsewhere, and the Irish law of evidence is no exception in this regard. Writing about the impact on legal cultures, Nelken ${ }^{137}$ has argued that with the publication of league tables etc, legal cultures are undeniably becoming increasingly 'relational', by which he means the extent to which attitudes and behaviour are influenced by information about what is happening elsewhere. The result is that countries try to come into line, in terms of their imprisonment rates, for example, so as not to be too distant from the norm or average of other countries. Karstedt ${ }^{138}$ has made similar arguments about the increasingly reflexive nature of criminal justice policymaking, but in the narrower sense of countries being influenced by groups of 'cultural peers', such as those from which they have borrowed policies before, which in the Irish legal context is common law countries such as the UK, and, increasingly, the European Court of Human Rights. And yet, as Loader and Sparks observe, 'It is precisely under globalising conditions that people's sense of place and of differences between here/there, inside/outside, us/them - takes on a renewed force as a structuring feature of social relations and culture'. ${ }^{139}$ Relating this to the instant case study, it is interesting to observe some of these tensions playing out in JC and what may be described as a self-consciousness about the Irish legal position militating strongly in favour of reform for the majority. O'Donnell J, for example, embarks on a long and detailed excursus of the evidentiary rules in other common law jurisdictions in order to identify Ireland as an outlier among them: 'it seems clear that Kenny represents a near absolute exclusion which is the most extreme position adopted in the common law world'. ${ }^{140}$ MacMenamin J also invoked the ECHR:

\footnotetext{
${ }^{131}$ People (DPP) v JC [2015] IESC 31 (Clarke J) para 4.25.

${ }^{132}$ See further on this point, Hamilton (with Gough), above n 26, recommendation 1.

${ }^{133}$ LM Friedman 'Is there a modern legal culture?' (1994) 7 Ratio Juris 117; Ginsburg, above n 18.

${ }^{134}$ Ginsburg, above n 18 , at 99 .

${ }^{135}$ Fennell, above n 102, para 8.101, describes Damache as 'something of a shock wave to the Irish criminal justice system' and 'very much in line with the protectionist approach of the Supreme Court in Kenny'.

${ }^{136}$ Kilcommins above n 23, at 339 .

${ }^{137}$ Nelken, above n 10.

${ }^{138} \mathrm{~S}$ Karstedt 'Cultural peers and penal policies: a configurational approach toward mapping penal landscapes' (2015) 17

(3) Punishment and Society 374.

${ }^{139}$ I Loader and R Sparks 'Contemporary landscapes of crime, order and control' in Maguire et al, above n 90, p 94.

${ }^{140} D P P$ v JC, above n 3, O’Donnell J at para 95.
} 
The reputation and integrity of the system of justice should not be adversely affected by [a] properly and faithfully applied good faith exception to the rule, constitutionally applied here, as in other jurisdictions. The bar set by the majority judgments herein is significantly higher than that to be found elsewhere in the common law world. It is in no way inconsistent with the ECHR. ${ }^{141}$

McKechnie J for the minority, on the other hand, appears unimpressed with the argument that we should follow in the footsteps of other jurisdictions, emphasising the distinctly Irish approach to the exclusion of unconstitutionally obtained evidence, and the protectionist principles upon which it is founded:

This is what I have seen: as great as the show may be, it is not for me and I suspect not for a great number of others whose bedfellow is the 1937 Constitution of Ireland. Accordingly, I cannot see how, with worthwhile benefit, this Court should absorb into its case law, jurisprudence which has been established on fundamentally different principles to those which Kenny applied. ${ }^{142}$

The tensions generated by such comparisons provide an interesting read on legal culture and the way in which jurisdictions now seek to define, and commensurate, themselves in relation to others. In this case what is particularly interesting is the fact that the ECHR does not require the exclusion of unlawfully obtained evidence, ${ }^{143}$ and this fact is being used to effectively facilitate the 'reading down' of previously established rights of accused persons. ${ }^{144}$ Of course, there are also instances where the ECHR may require a higher standard of rights defence than the Irish regime, and this is evident in another watershed decision on the right to legal advice in custody delivered by the Supreme Court just one year prior to $J C .^{145}$

\section{Conclusion}

The largely due process oriented legal culture in Ireland, born out of the capacious judicial imagination of Brian Walsh and other visionaries of the 1960s, 70s and 80s, has traditionally exerted a protective effect, with the exclusionary rule providing one of the most tangible protections for suspect rights within the Irish criminal process. The undercutting of the rule, one of the strictest in the common law world, in DPP $v$ JC therefore marks an important watershed in Irish legal history and one that requires explanation. Employing the concept of 'legal culture' as a lens, this paper has argued, following Friedman, that legal change is best understood as a product of social forces, triggered largely from the 'outside' but engaged in a constant dialectic with an internal legal culture that is itself far from inert and univocal. The relationship is therefore not straightforward and, as the Irish example has shown, cannot be reduced to a view of internal culture simply 'mediating' external social forces, even where the latter appear to have 'caught up' with the former. Indeed, the very fact that it was a decision with an underlying due process rationale - Damache - that would, ironically, act as a final catalyst to the undoing of the Kenny rule, serves to reinforce this point.

It will be recalled that Friedman originally approached legal culture, with its external and internal dimensions, as a way of interpreting rapid social, economic and technological change at a macro level and the (differential) response of modern law to these demands. This paper has aimed to show how the Friedmanite distinction retains much utility also as an analytic tool in interpreting the cultural

\footnotetext{
${ }^{141} D P P$ v JC, above n 3, MacMenamin J at para 78.

${ }^{142}$ DPP $v$ JC, above n 3, McKechnie J at para 200.

${ }^{143}$ See Hamilton (with Gough), above n 26 at p 18: 'the ECHR does not contain rules on admissibility of evidence and the ECtHR has yet to pronounce a comprehensive exclusionary remedy for breaches of Convention rights'.

${ }^{144}$ See Fennell, above n 102.

${ }^{145}$ In DPP $v$ Gormley, above $\mathrm{n} 97$, the Supreme Court held that pre-trial detention questioning (though not forensic sampling) without access to a lawyer is in breach of the right to trial in due course of law. In arriving at its conclusion it was heavily influenced by the ECHR decision in Salduz v Turkey [2009] 49 EHRR 19.
} 
assumptions and logics at work at the micro level of judicial decision-making. While of course Friedman's concern was to look at the 'forest' and not the trees, ${ }^{146}$ moving beyond doctrinal and court-centred ways of thinking, the distinction is highly useful also in illuminating the dialectic between the 'social' and the 'legal' at this level. Not unlike other authors, who have sought to show how the judicial construction of rights and liability is attached to the broader cultural and political discourse, with important implications for gender ${ }^{147}$ and race, ${ }^{148}$ this paper links this interplay to broader cultural shifts towards a more expressive and populist justice system. This argument, first articulated by David Garland in his masterful Culture of Control in 2001, has been mainly applied to the penal system, but more recently extended to criminal evidence rules that are perceived to help the guilty to 'get away with it.' ${ }^{149}$ Against this background, close, nearly forensic, analysis of seminal court decisions such as $J C$, as well as their antecedents and context, allows us to hold these two foci in the frame at the same time, attending to a largely external, more victim-focused rhetoric, but also to the critical internal 'structure of justification' ${ }^{150}$ by which an outcome appears logical and inevitable. As we have seen, in a more globalised legal world, such structures may also increasingly include a heightened self-consciousness about domestic legal positions, a reflex that is capable of both enhancing and diluting due process protections.

\footnotetext{
${ }^{146}$ Ginsburg, above n 18 , at 97.

${ }^{147}$ A Scales, “Nobody broke it, it just broke”: causation as an instrument of obfuscation and oppression' in D Engel and M McCann (eds) Fault Lines: Tort Law as Cultural Practice (Stanford University Press, 2009). She refers to the McDonald's coffee case brought by Stella Liebeck when she was burned by their coffee, which she claims follows a kind of 'rape narrative'.

${ }^{148}$ M Chanock The Making of South African Legal Culture 1902-1936: Fear, Favour and Prejudice (Cambridge: Cambridge University Press, 2001).

${ }^{149} \mathrm{H}$ Quirke 'Criminal evidence and the culture of control', DCU Criminal Evidence and Procedure Workshop, 12 October 2018. See also Kilcommins et al, above n 87, p 142, who argue that Garland 'devoted little attention to the dwindling power of the accused vis-à-vis the state'.

${ }^{150}$ E Weinrib 'The jurisprudence of legal formalism' (1993) 16 Harvard Journal of Law and Public Policy 583.
}

Cite this article: Hamilton C (2021). Interpreting change through legal culture: the case of the Irish exclusionary rule. Legal Studies 41, 355-372. https://doi.org/10.1017/1st.2021.3 